\title{
DISKURSUS PEMILIHAN GUBERNUR DI MEDIA LOKAL
}

\author{
Dinul Fitrah Mubaraq \\ Dosen Fakultas Ushuluddin, Adab dan Dakwah IAIN Parepare \\ Email: dinulfitrahm84@gmail.com
}

\begin{abstract}
Abstrak
Penelitian ini membahas tentang konstruksi realitas pemilihan gubernur di media local, sebuah studi komunikasi politik tentang wacana calon Gubernur Sulsel 2018 pada Harian Fajar dan Celebes TV. Tujuan penelitian ini adalah menganalisis teks pemberitaan calon gubernur Sulsel periode 2018 pada Harian Fajar dan Celebes TV, dan menganalisis praktik diskursus Harian Fajar dan Celebes TV dalam pengkonstruksian realitas Pilgub Sulsel periode 2018. Hasil penelitian menunjukkan bahwa teks berita Harian Fajar dan program siaran Celebes TV cenderung mengkonstruksi isu-isu populis mengenai realitas politik jelang Pilgub Sulsel 2018. Penonjolan kekuatan elit, parpol dan kelompok dominan serta pemarginalan posisi kontestan pilgub dikonstruksi dalam teks berita dengan penekanan pada elemen wacana; semantik, stilistik, skema relasi dan identitas aktor politik. Konstuksi teks berita tentang realitas Pilgub Sulsel 2018 memberi kesan bahwa entitas media lokal berkarakter partisan, namun pemihakannya pada kepentingan kelompok dominan berlangsung secara samar dan dramatis dengan mengendalikan teks secara interdiskursif. Praktik wacana di ruang redaksi menunjukkan peran sentral redaktur tidak hanya sebatas agen pendefinisi realitas, tetapi juga sebagai political player dalam kontestasi wacana Pilgub Sulsel 2018. Redaktur memiliki kuasa atas teks yang mampu menciptakan isu politik dalam pemberitaan sekaligus berkuasa menentukan arah wacana yang dikonstruksinya.
\end{abstract}

Kata Kunci: diskursus, pemilihan gubernur, studi komunikasi politik

\section{PENDAHULUAN}

Pengemasan "isu politik" melalui media dianggap penting untuk menggiring opini publik tentang bentukan citra calon kepala daerah. McNair dalam uraian Hamad, ${ }^{1}$ menyatakan bahwa dalam komunikasi politik, aspek pembentukan opini justru menjadi tujuan utama, karena hal ini akan menentukan pencapaian politik para aktor politik. Senada dengan Ibrahim yang berpendapat bahwa faktor penting kesuksesan politik dewasa ini adalah dengan mengeksploitasi bebagai tawaran media untuk memproyeksikan profil seseorang sekaligus untuk memanipulasi publik. ${ }^{2}$

Media lokal mainstream di Sulawesi Selatan cenderung menampilkan wacana yang berbeda tentang isu calon gubernur Sulawesi Selatan 2018. Hasil studi pendahuluan menunjukkan bahwa publikasi berita yang ditampilkan media 
mainstream di Sulawesi Selatan dominan mengangkat wacana komunikasi politik di antara calon gubernur untuk saling menjajaki kemungkinan berpaket pada Pilgub Sulsel 2018, dan beragam peristiwa kampanye atau sosialisasi figur politik yang dilakukan oleh simpatisan atau tim pemenangan di berbagai daerah. Sejumlah namanama figur politik kemudian dikerucutkan menjadi tiga paket sebagaimana yang dikonstruksi sejumlah media lokal Sulawesi Selatan, di antaranya Nurdin Halid berpasangan dengan Aziz Qahhar Mudzakkar (NH-Azis), Nurdin Abdullah berpasangan dengan Andi Sudirman Sulaiman (NA-ASS). dan Ichsan Yasin Limpo berpasangan dengan Andi Mudzakkar (IYL-Cakka).

Narasi tekstual yang ditampilkan media mampu menggiring penafsiran pembaca dan pada umumnya masyarakat pemilih pada pola pemaketan calon gubernur, dimana dasar pembenar atau objektivasi persitiwa itu tidak lain disandarkan pada klaim rasionalitas hasil survei tentang popoularitas, akseptabilitas dan elektabilitas kandidat disamping manuver politik kelompok kepentingan yang termediasi untuk mencapai dukungan publik yang massif. Berangkat dari latar permasalahan tersebut, maka penting untuk menganalisis wacana tentang calon Gubernur Sulawesi Selatan 2018 yang dikonstruksi oleh media lokal. Pokok permasalahan penelitian ini adalah bagaimana konstruksi realitas politik menjelang pemilihan gubernur Sulsel 2018 di media lokal. Permasalahan tersebut kemudian dijabarkan ke dalam sub permasalahan, yakni (1) bagaimana konstruksi teks pemberitaan calon gubernur Sulsel periode 2018 pada Harian Fajar dan Celebes TV, (2) bagaimana praktik diskursus Harian Fajar dan Celebes TV dalam mengkonstruksi realitas Pilgub Sulsel periode 2018.

\section{TINJAUAN TEORETIS}

\section{Teks Berita dalam Paradigma Kritis}

Pendekatan paradigma yang menjadi landasan teoretis dan metodologis penelitian ini adalah paradigma kiritis khususnya berkenaan dengan subject matter komunikasi politik. Paradigma kritis yang bertitiktolak pada ide Karl Marx yang selanjutnya dikembangkan oleh Max Hokheimer (1895-1973), Herbert Marcuse (1898-1979) dan TheodorWiesengrund Adorno (1903-1969) di Institut Penelitian Sosial Frankfurt-Jerman. ${ }^{3}$ Paradigma kritis mempunyai pandangan tersendiri terhadap berita yang disajikan oleh media melalui bagaimana berita tersebut diproduksi dan bagaimana kedudukan wartawan dan media bersangkutan dalam keseluruhan proses produksi berita. Dalam konsepsi paradigma kritis, ada empat aspek yang menjadi fokus perhatian untuk menganalisis berita dan media, yaitu mengenai fakta, posisi media, posisi wartawan, dan hasil liputan. ${ }^{4}$

\section{Critical Discourse Analaysis}

Salah satu konsep analisis teks media yang berparadigma kritis dikenal dengan istilah Critical Discourse Analysis (CDA). ${ }^{5}$ Secara etimologi kata discourse berasal dari bahasa Latin "discurrere" (mengalir ke sana ke mari) dari nominalisasi kata "discursus" yang berarti mengalir secara terpisah yang ditransfer maknanya menjadi terlibat dalam sesuatu, atau memberi informasi tentang sesuatu. ${ }^{6}$ Istilah 
analisis wacana adalah istilah umum yang dipakai dalam banyak disiplin ilmu dan dengan berbagai pengertian. Meskipun ada gradasi yang besar dari berbagai definisi, titik singgungnya adalah analisis wacana berhubungan dengan dengan studi bahasa atau konteks sosial pemakaian bahasa. Menurut Hikam dalam uraian Eriyanto, ${ }^{7}$ secara garis besarnya analisis wacana paling tidak, dapat ditinjau dalam tiga perspektif, yaitu Positivisme-Empiris, Konstruktivisme dan Kritis

Pandangan Kritis mengoreksi pandangan konstruktivisme yang diangap kurang sensitif pada proses produksi dan reproduksi makna yang terjadi secara historis maupun institusional, belum menganalisis faktor-faktor relasi kekuasaan yang inheren dalam setiap wacana yang pada gilirannya membentuk jenis-jenis subjek tertentu berikut perilaku-perilakunya. Dalam hal inilah yang melahirkan paradigma kritis terutama analisis wacana yang bersifat kritis (CDA).

CDA tidak dipahami semata sebagai studi bahasa, tetapi juga menghubungkan dengan konteks dan praktik tertentu, termasuk dalam praktik politik dan kekuasaan. ${ }^{8}$ Berdasarkan cakupan analisisnya, ada lima karakteristik umum CDA seperti yang tersebar dalam tulisan Teun A. Van Dijk, Wodak dan N. Fairclough, ${ }^{9}$ yakni Tindakan, Konteks, Historis, Kekuasaan, Ideologi. Berdasarkan relevansinya dengan fokus masalah, landasan paradigma dan teori, penelitian ini menggunakan CDA model Fairclough. ${ }^{10}$ Asumsi teoretis CDA model Fairclough adalah upaya menghubungkan teks yang mikro dengan konteks masyarakat yang makro. Fairclough menegaskan bahwa bahasa adalah praktik kekuasaan, bahasa membawa konsekuensi tertentu, dimana bahasa secara sosial dan historis adalah bentuk tindakan dalam hubungan dialektik dengan struktur sosial.

Critical Discourse Analysis model Fairclough mengintegrasikan secara bersama-sama antara analisis lingusitik dan pemikiran sosial politik (sociopolitical linguistic) dan secara umum menganalisis perubahan sosial. Fairclough menggunakan term wacana untuk menjelaskan bentuk pemakaian bahasa sebagai praktik sosial, lebih dari aktivitas individu atau sekedar merefleksikan sesuatu. ${ }^{11}$ Fairclough membagi analisis wacana ke dalam tiga dimensi, antara lain; teks, praktik diskursus, dan praktik sosiokultural.

\section{Komunikasi Politik dan Media Massa}

Komunikasi politik menurut Surbakti adalah proses penyampaian informasi mengenai politikdari pemerintah kepada masyarakat dan dari masyarakat kepada pemerintah. ${ }^{12}$ Pengertian senada diungkapkan oleh Halik, bahwa pada tataran arus bergulirnya pesan politik, komunikasi politik berlangsung dalam dua level, yakni di level sistem politik dan yang berlangsung di ruang publik, sebuah arus komunikasi top down dan arus komunikasi yang bersifat bottom up atau dari publik menuju elit. ${ }^{13}$ Rush dan Althoff, menjelaskan bahwa komunikasi politik adalah suatu proses dimana informasi politik yang relevan diteruskan dari satu bagian sistem politik kepada sistem politik yang lain dan antara sistemsistem sosial dengan sistemsistem politik. ${ }^{14}$

Almond dan Powel menempatkan komunikasi politik sebagai suatu fungsi politik bersamasama dengan fungsi artikulasi, agregasi, sosialisasi dan rekrutmen yang terdapat dalam suatu sistem politik. Demikian juga Meadow yang menyatakan 
bahwa komunikasi politik meliputi segala bentuk pertukaran simbol atau pesan yang pada tingkat tertentu dipengaruhi atau memengaruhi berfungsinya sistem politik. ${ }^{15}$ Dapat disimpulkan bahwa bahwa komunikasi politik memainkan peranan yang sangat penting dan strategis di dalam sistem politik, terutama menjadi bagian yang menentukan dalam sosialisasi politik, partisipasi politik dan perekrutan politik. Selain itu, pendapat Rush dan Althof juga relavan dikaitkan dalam konteks bahasan ini, bahwa aktivitas politik individu sangat ditentukan oleh komunikasi politik. ${ }^{16}$

Unsur pertama dalam studi komunikasi politik menurut McNair adalah organisasi politik yang mencakup partai politik, organisasi publik, kelompok penekan dan pemerintah. ${ }^{17}$ Unsur kedua adalah publik yang menurut McNair tujuan proses komunikasi politik sejatinya untuk meyakinkan publik. Publik sebagai target komunikasi politik sangat luas, namun semua komunikasi politik ditujukan untuk menimbulkan pengaruh terhadap penerima pesan. ${ }^{18}$ Unsur ketiga dalam proses komunikasi politik adalah organisasi media, dimana McNair menyebut tiga jenis media massa, yakni media cetak, siar dan online. Peran media dalam sistem politik demokrasi sebagaimana pandangan McNair, di satu sisi media berfungsi sebagai pengirim pesan komunikasi politik yang berasal dari luar organisasi media itu sendiri, dan pada aspek yang lain sebagai penyalur pesan politik yang disusun oleh waratawan dan produsen eksternal media seperti blogger.

Rosen dalam uraian Masduksi, menyatakan dalam tradisi jurnalisme politik, media adalah pemain atau alat yang dikendalikan pihak di luar pengelola media itu. ${ }^{19}$ McNair berpendapat bahwa media itu sendiri, atau mereka yang bekerja di dalamnya, mesti dipandang sebagai "pelaku penting" dalam politik, tidak hanya menyampaikan pesan organisasi politik kepada publik, namun juga mengubahnya melalui berbagai proses pemberitaan dan interpretasi. Hubungan antara media dan proses politik bersifat dialektika, melibatkan aksi dan reaksi. Media melaporkan dan menganalisa kegiatan politik, namun mereka juga merupakan bagian darinya, yakni sebagai sumberdaya bagi para pelaku dan penasihat politik. ${ }^{20}$

Menurut Chomsky, pada awalnya dikenal sebagai jurnalisme propanganda, yaitu praktek jurnalisme "siap saji" (fast food) mewadahi kepentingan dominan yang pada umumnya dikontrol oleh uang dan kekuasaan pejabat negara (controlled by the moneyed and power elite). Model propaganda adalah model posisi media yang dikontrol kekuatan elit dan media melalukan sensor internal untuk memproteksi masuknya ide-ide populis yang berbasis kesadaran publik. Dalam jurnalisme propaganda, media tidak menganut semangat memberikan pendidikan politik yang sehat (voters and electoral eduacation), media membiarkan diri menjadi political public relations para kandidat. ${ }^{21}$

Menurut Chomsky, kecenderungan media menjadi propaganda terutama di musim kompetisi pemilu merupakan akibat dari beragam aspek. Pertama, terkonsentrasi pemilikan media pada sekelompok elit kekuatan ekonomi, sejumlah konglomerat yang secara keamanan bisnis (business safety) masih sangat tergantung pada kekuatan politik yang sedang atau akan berkuasa. Kedua, orientasi komersial yang terlampau berlebihan, penggunaan iklan sebagai sumber utama pendapatan (primary source of income) bisnis media. ${ }^{22}$ Ketiga, tradisi jurnalistik yang masih 
konvensional, menggantungkan sumber informasinya pada tiga lingkaran elit dalam masyarakat yaitu kalangan bisnis, pemerintah dan pakar, akademis atau peneliti. Keempat, mengedepankan norma "kalah menang" dalam politik, sebagai bagian dari disiplin peliputan media atas pelaksanaan pemilu. Media terjebak untuk mengadu dua atau lebih kandidat dengan menghitung kecepatan mereka berlari mengejar kuantitas dukungan, tanpa peduli apakah dukungan itu diraih dengan cara mobilisasi semu atau pendidikan politik yang memadai. ${ }^{23}$

\section{Perspektif Ekonomi Politik Kritis}

Menurut McQuail, teori ekonomi politik adalah pendekatan kritik sosial yang memfokuskan pada hubungan antar struktur ekonomi dan dinamika industri media serta konten ideologis media. Dari sudut pandang ini, lembaga media dianggap sebagai bagian dari sistem ekonomi dalam hubungan erat dengan sistem politik. Konsekuensinya seperti terlihat dengan berkurangnya sumber media yang independen, konsentrasi pada khalayak yang lebih besar, menghindari resiko dan mengurangi penanaman modal pada tugas media yang kurang menguntungkan. Ditemukan juga adanya pengabaian pada sektor khalayak potensial yang lebih kecil dan miskin, dan sering terdapat media berita yang tidak seimbang. ${ }^{24}$

Menurut Golding dan Murdock dalam uraian Halik, pendekatan ekonomi politik yang bersifat kritis terbagi atas tiga varian. Pertama, instrumentalis, melihat faktor ekonomi sebagai faktor dominan dan menentukan media. Media dipandang sebagai instrumen dominasi kelas. Kedua, konstruktivis, yang memandang ekonomi media tidak hanya dipengaruhi oleh faktor ekonomi saja, tetapi juga faktor lainnya seperti individu dan budaya. Proses dalam media melibatkan politik pemaknaan, penandaan dan pemberitaan yang rumit. Ketiga, strukturalis, di mana fokus perhatiannya pada relasi dan pergulatan unsur-unsur dalam struktur internal media dengan faktor-faktor eksternal. Pendekatan strukturalis melihat struktur bersifat solid, permanen dan tidak dapat dipindahkan. ${ }^{25}$

Komodifikasi adalah titik masuk awal untuk menteorisasikan ekonomi politik komunikasi. Pembahasan ini mengangkat tema 'komodifikasi' dalam kaitan dengan kajian budaya dan ekonomi politik media. Mendefinisikan komodifikasi sebagai proses mengubah barang dan jasa termasuk komunikasi yang dinilai karena kegunaannya, menjadi komoditas yang dinilai karena apa yang akan mereka berikan pasar. Mosco mengupas kembali apa yang disebut oleh Marx sebagai kulit bawang (onion skin) penampilan komoditas yang menyingkapkan sistem produksi. ${ }^{26}$ Secara umum ada tiga tipe komunikasi yang penting bagi komunikasi, yakni komodifikasi isi, komodifikasi khalayak, dan komodifikasi tenaga kerja. ${ }^{27}$ 


\section{KONSTRUKSI REALITAS PILGUB SULSEL DI MEDIA LOKAL}

\section{Politik Pemaknaan dalam Teks Berita Pemilihan Gubernur Sulsel 2018}

Dari hasil penelitian menunjukkan bahwa politik pemaknaan media menyebar pada seluruh struktur teks pemberitaan. Dikaitkan dengan teks berita mengenai realitas politik jelang Pilgub Sulsel 2018 yang dikonstruksi oleh media lokal, dimensi politik pemaknaan yang paling mendasar adalah pengkonstruksian realitas politik ke dalam satu set kategori yang disebut sebagai rubrik politik (misal pada Harian Fajar) atau bincang politik (contoh pada Celebes TV). Kategorisasi ini tidak hanya sebatas mengklasifikasikan peristiwa politik menjadi lebih spesifik, tetapi seperti istilah yang diungkapkan Fairclough tentang "order of discourse", sebuah praktik pendisiplinan wacana dimana wartawan dikendalikan dalam memroduksi teks.

Praktik diskursif pada umumnya menjadi framework media yang menghasilkan struktur wacana (teks berita). Namun demikian, teks berita itu sendiri tidak hadir begitu saja sebagai sebuah refleksi atas realitas yang diproduksi atau direproduksi, melainkan penciptaan ruang simbolik di mana hal itu memungkinkan politik pemaknaan dimapankan melalui perantaraan bahasa. Berkenaan dengan diskursus politik jelang Pilgub Sulsel 2018, temuan data menunjukkan bahwa konstruksi teks berita media lokal lebih cenderung menggiring wacana kekuatan pasangan calon gubernur dan wakil gubernur, NH-AQM, dengan menyertakan wacana dominasi parpol pengusung dan penguatan wacana melalui opinion leader.

Teks berita semacam itu bermakna ganda tidak hanya berarti mengunggulkan kandidat tersebut, tetapi juga dapat meminggirkan kandidat dalam wacana. Teks berita yang objektif dapat memarginalkan kandidat, misalnya NH-AQM atau sebaliknya memihak pada kandidat lainnya, AAN-TBL, atau NH-ASS, atau IYLCakka. Sebagaimana yang telah disinggung sebelumnya, eksistensi NH-AQM dalam diskursus Pilgub Sulsel 2018 lebih dominan dibandingkan pasangan calon lainnya seperti terlihat pada tema utama (tematik) yang dikembangkan dalam pemberitaan media lokal.

Selalu ada alasan pembenar bagi redaktur/produser untuk mengedepankan tema dominan tersebut, yakni sesuai realitas politik yang berkembang di tengah masyarakat di antaranya partai politik yang mengusung $\mathrm{NH}-\mathrm{AQM}$ rata-rata parpol besar, dukungan elit politik dan penguasa, opinion leader baik tokoh publikmaupun pengamat politik yang semuanya mendukung gagasan inti wartawan dalam mengkonstruksi narasi besar (grand narative) kandidat terkuat. Meskipun demikian, semua posisi para aktor komunikasi politik dalam kontestasi Pilgub Sulsel 2018 dimediasi atau diberikan ruang ekspresi sebagai subjek aktif yang menyalurkan opini, komentar maupun gagasannya. Namun pemberian akses dan ruang ekspresi tidak merata, justru ruang ekspresi lebih memihak pada kelompok elit dominan, tokoh publik dan opinion leader.

Dominasi kelompok elit dalam ruang eskpresi ini secara tidak langsung berpengaruh terhadap proses produksi dan reproduksi wacana di mana pemberitaan media lokal cenderung memenangkan wacana kelompok dominan. Peran media di sini tidak hanya memfasilitasi wacana politik atau sekedar menarasikan kepentingan 
kelompok tertentu, tetapi media juga melakukan politik pemaknaan terhadap realitas Pilgub Sulsel 2018 yang dikonstruksinya. Selain diwujudkan melalui tema sentral pemberitaan, politik pemaknaan ini dikonstruksi dalam skema pemberitaan (skematik), dari satu wacana dengan wacana lainnya dibenturkan dalam satu teks berita.

Sebagai contoh, di awal periode penjaringan kandidat oleh seluruh parpol, media menggulirkan wacana survei tentang popularitas dan elektabilitas sejumlah figur politik yang dianggap potensial untuk diusung di Pilgub Sulsel 2018. Perang wacana antarlembaga survei sangat menonjol, namun realitas konsistensi hasil survey dari satu lembaga survei dengan lembaga survei lainnya memiliki perbedaan yang signifikan. ${ }^{28}$ Di balik pertarungan wacana itulah politik pemosisian figur dituangkan ke dalam teks pemberitaan, di mana redaktur menyusun skema berita secara dialektis.

Skema wacana yang dibangun oleh redaktur di satu pihak lebih menonjolkan satu kandidat, misalnya NH memiliki tingkat elektabilitas tinggi dibanding kandidat lainnya berdasarkan klaim parpol atas hasil surveinya. Sementara pada teks yang berbeda, redaktur mengkonstruksi wacana tandingan, misalnya dari segi popularitas IYL lebih unggul dibanding NH,NA dan AAN. ${ }^{29}$ Politik pemosisian ini terutama disandarkan pada klaim lembaga survei yang berupaya meyakinkan bahwa survei mereka menggunakan metode ilmiah dan akurat bahkan sering diperkuat dengan argumentasi para pengamat politik untuk memvalidasi hasil survei tersebut.

Temuan data penelitian ini menunjukkan bahwa politik pemaknaan redaktur/produser atas realitas politik Pilgub Sulsel 2018 lebih menonjol pada level semantik dan stilistik. Dengan wacana tandingan seperti yang disebutkan tadi, menunjukkan dengan jelas kecenderungan politik pemaknaan oleh redaktur/produser terutama dengan cara manakar kekuatan antarkandidat. Melalui praktik pemaknaan (semantik), kontrol informasi oleh redaktur/produser menjadi mungkin, menonjolkan kekuatan dominan seorang kandidat berdasarkan rasionalitas hasil survei, atau sebaliknya memarginalkan posisi kandidat lainnya hanya karena wacana lembaga survei kurang mendukungnya.

Praktik pemaknaan redaktur/produser di ruang redaksi erat kaitannya dengan pertimbangan ideologi, ekonomi dan politik media, di mana redaktur/produser cenderung hanya mengusung logika nilai berita dengan magnitude (daya dentum) yang tinggi. Karena itu ada pihak yang kesulitan menjangkau akses atau kurang termediasi dalam wacana yang dikonstruksi oleh media, sebab aktor politik yang hendak berelasi dengan redaktur/produser sebagai pendefinisi realitas politik, harus mampu merekayasa peristiwa dan tindakan politiknya di ruang publik sehingga nantinya memenuhi logika magnitude yang disyaratkan media sebagai nilai berita yang utama dalam rubrikasi politik ataupun dalam program bincang politik. ${ }^{30}$ Nilai berita sebagai ideologi profesional redaktur/produser-seperti yang telah diuraikan terdahulu-merupakan konstrukideologi media itu sendiri.

Ideologi Harian Fajar maupun Celebes TV sama-sama mencerminkan watak bisnis. Itulah sebabnya kedua media ini, di ranah pemberitaan lebih mengutamakan liputan peristiwa politik yang memiliki nilai berita tinggi, selaras dengan orientasi profit pemilik media. Meskipun ideologi kapital dalam praktik kekuasaan pemilik 
media tidak dijalankan dengan intervensi secara langsung, tetapi memengaruhi mainframe editorial policy media tersebut, di mana berita harus dirancang sedemikian rupa ibarat barang dagangan yang harus laku terjual dan pembaca/pemirsa hanya dipandang sebagai konsumen semata.

Redaktur/produser terseret dalam lingkaran kepentingan ekonomi politik media yang secara tidak disadari menciptakan aktor politik media yang mana mereka dituntut agar mampu mengkonstruksi realitas politik untuk memenuhi kepentingan kapital pemilik media. Sebagai aktor politik media, redaktur/produser juga dituntut berelasi dengan kelompok elit dalam rangka memenuhi komoditas informasi. Hal ini tercermin dalam teks pemberitaan Harian Fajar dan program siaran Celebes TV yang lebih dominan menyuarakan kelompok elit dan yang ditonjolkan dalam pemberitaan cenderung hanya komentar elit parpol, pengamat politik, tokoh publik dan perseteruan antarpartai dan antarkandidat dalam upaya meraih kemenangan di Pilgub Sulsel 2018.

\section{Praktik Sosiokultural dalam Momentum Pilgub Sulsel 2018}

Salah satu dimensi sosiokultural yang dimaksud dalam pembahasan ini adalah level institusional, melihat bagaimana pengaruh institusi organisasi dalam praktik produksi wacana. Institusi ini berasal dari dalam diri media sendiri dan juga kekuatan-kekuatan eksternal di luar media yang menentukan proses produksi berita. Titik penting berkenaan dengan institusi media adalah ekonomi media. Produksi berita di media tidak mungkin dilepaskan dari pengaruh ekonomi media yang sedikit banyak berpengaruh terhadap wacana yang muncul dalam pemberitaan. Dalam konteks ekonomi media, Chomsky memaparkan adanya kondisi dan situasi yang disebut sebagai faktor penentu (filter) yang memengaruhi isi media, di antaranya iklan sebagai sumber pemasukan utama bagi media, ukuran kepemilikan terpusat dan orientasi profit media, dan sumber berita. ${ }^{31}$

Kecenderungan media saat ini sangat bergantung pada iklan. Penggunaan iklan menjadi sumber utama pendapatan (primary source of income) bisnis media. Sebagaimana yang telah disinggung dalam pembahasan sebelumnya, konstruksi berita politik Harian Fajar dan Celebes TV terutama mengenai wacana Pilgub 2018 dikonstruksi berbasis nilai magnitude. Dengan kata lain berita harus dibuat sedemikian rupa agar mampu menarik antusiasme pembaca/pemirsa sehingga nantinya orang berminat memasang iklan di media tersebut. Dalam konteks ini, selain masyarakat umum, menurut penuturan redaktur politik Harian Fajar, semua aktor politik maupun kandidat Pilgub Sulsel juga dipandang sebagai pembaca. Namun demikian, aktor politik di sini tidak hanya sebatas konsumen pembaca, tetapi di ranah periklanan politik (political advertising), justru kandidat itu sendiri sebagai subjek pengiklan yang mendominasi ruang periklanan, di mana pertarungan image juga berlangsung di ruang ini.

Keberadaan pengiklan berkorelasi dengan khalayak pembaca/pemirsa, yang dalam industri media penerbitan seperti Harian Fajar, disebut sebagai oplah sementara di media penyiaran seperti Celebes TV disebut rating. Baik oplah maupun rating sama menuntut kuantitas atau seberapa banyak khalayak pembaca/pemirsa 
yang dapat diraih dan ujungnya adalah pencapaian profit dari iklan. Karena berpretensi menarik khalayak sebanyak mungkin, maka wartawan yang memroduksi berita harus menciptakan "berita yang baik" agar disukai banyak orang atau bisa dijual dan menarik khalayak pembaca/pemirsa. Semakin banyak konten yang dikonsumsi pembaca/pemirsa, maka semakin besar pula profit yang diterima media. Dalam konteks inilah isu Pilgub Sulsel 2018 sangat berpotensi untuk didramatisasi dan dipolitisasi di mana pengkonstruksian berita politik diorientasikan untuk kepentingan ekonomi media, dengan kata lain sedapat mungkin berita itu mampu meningkatkan jumlah pembaca/pemirsa dan pada akhirnya pengiklan, terutama iklan politik kandidat yang budget-nya relatif besar.

Intervensi institusi ekonomi media yang lainnya adalah modal atau kepemilikan terhadap media. Konsentrasi kepemilikian media yang terpusat juga harus dikaitkan secara luas dengan jaring-jaring kapitalisme yang merambah di daerah. Harian Fajar yang dimiliki oleh Alwi Hamu merupakan bagian dari Jawa Pos Grup. Jawa Pos Grup sendiri adalah grup media terbesar di Sulawesi Selatan bahkan juga di kawasan Indonesia Timur. ${ }^{32}$ Harian Fajar mengalami perkembangan pesat sejak bergabung dalam Jawa Pos Grup. ${ }^{33}$ Harian Fajar telah berkembang di wilayah Sulawesi Selatan sebagai korporasi yang mendominasi (monopoli profit media lokal) dengan pemilikan jaringan surat kabar lokal di antaranya Ujung Pandang Ekspres, Berita Kota Makassar, Pare Pos, Palopo Pos, Kendari Pos, dan lainnya.

Celebes TV berada di bawah kendali korporasi Bosowa Grup yang dimiliki oleh Aksa Mahmud dan Erwin Aksa dengan nama perusahaan PT. Sunu Network Broadcast Televisi. Bosowa Grup memiliki sejumlah perusahaan lokal maupun nasional. ${ }^{34}$ Celebes TV menjalin kerjasama dengan PT Media Televisi Indonesia perusahaan pemilik Metro TV dan Kompas Gramedia. Kerjasama ini berupa dukungan untuk operasional siaran televisi lokal yang merupakan anak perusahaan Bosowa Corporation. Selain itu, Celebes TV juga memiliki jaringan media lokal di antaranya Celebes Online, Bosowa Radio dan termasuk Tribun Timur.

Konsentrasi kepemilikian kedua media tersebut mengindikasikan bahwa media tampak semakin digerakkan oleh motif bisnis atau spirit kapitalisme. Implikasinya kemudian, baik Harian Fajar maupun Celebes TV yang memiliki basis korporasi berbeda, keduanya bersaing memperebutkan pangsa pasar di Sulawesi Selatan. Pada musim pemilu, terutama menjelang Pilgub Sulsel 2018, wartawan dari kedua media tersebut gencar meliput peristiwa politiksebanding dengan banyaknya berita dan iklan politik yang dipublikasikan/disiarkan. Momentum pilgub ini diibaratkan sebagai musim panen bagi kedua media tersebut untuk meraup keuntungan dari iklan politik yang digelontorkan parpol dan kandidat. Akumulasi modal yang terbilang banyak itu tentu saja menggiurkan para konglomerat media. Bukan hanya iklan politik yang menjadi komoditas media, isu-isu politik yang diwacanakan kepada publik juga bernuansa ekonomis, di mana berita harus memiliki "nilai jual" agar pembaca/pemirsa mau berlangganan di media tersebut. ${ }^{35}$

Selain ekonomi media, institusi politik dalam arti bagaimana media digunakan oleh kekuatan-kekuatan politik yang ada dalam masyarakat. Media menjadi instrumen kekuatan kelompok dominan untuk merendahkan atau memarginalkan 
kelompok lain dengan perantaraan kekuatan media. Menjelang penyelenggaraan Pilgub Sulsel 2018, berbagai isu digulirkan, misalnya perseteruan mengunci rekomendasi dalam proses penjaringan kandidat, saling kritik antarkandidat, kampanye hitam dan kampanye negatif dan lain sebagainya, semakin intens diwacanakan di ruang publik. Pertarungan wacana antarkandidat semakin memanas dan masing-masing kubu saling meng-counter setiap isu yang diberitakan.Dalam situasi inilah Harian Fajar dan Celebes TV memainkan perannya.

Eksistensi kedua media lokal tersebut di tengah pergulatan wacana pilgub ditandai dengan peran sebagai instrumen kepentingan politik (bagi parpol, politisi dan elit lokal) di satu sisi dan kepentingan ekonomi media di sisi yang lain. Orientasi kepentingan politik dan ekonomi tersebut pada akhirnya teraktualisasi dalam praktik disukursus di ruang redaksi. Seperti yang telah dipaparkan pada pembahasan terdahulu, praktik diskursus dalam ruang redaksi tidak berlangsung netral atau steril dari pengaruh kepentingan politik (personal dan institusional). Independensi media tidak lagi penting dipertanyakan, sebab media sejatinya"bermain dua kaki"atau "berwajah ganda" dalam kontestasi wacana Pilgub Sulsel 2018.

Pertarungan wacana antarparpol dan antarkandidat Pilgub Sulsel 2018 dimediasi oleh media lokal (Harian Fajar dan Celebes TV). Pemburukan citra parpol atau kandidat yang satu atas lainnya merupakan salah satu strategi politik yang mengemuka dari para aktor politik itu sendiri yang sering diaktualkan melalui media. Dalam beberapa kasus, media mengekspos isu sensitif tersebut, misalnya narasi besar partai Golkar yang selama ini diwacanakan mendominasi panggung politik di Sulawesi Selatan, ditenggelamkan dengan cara menelanjangi kasus korupsi yang dipersangkakan pada elitnya. ${ }^{36}$ Di sisi yang lain, media juga memainkan peran politisnya untuk mencitrakan parpol, politisi dan kandidat secara lebih baik di mata publik. Pencitraan positif para aktor politik-utamanya dalam berita-dilakukan dengan cara menunggangi komentar pengamat politik, opinion leader, rasionalitas survei, termasuk personafikasi kandidat yang dimediasi melalui iklan politik.

Penyajian realitas politik dari berbagai sisi memang penting diungkapkan oleh media, agar publik pembaca/pemirsa mengetahui kebenaran. Hanya saja informasi politik yang disajikan oleh media cenderung menggambarkan realitas politik yang parsial, lebih menyuarakan kepentingan kelompok yang berkuasa, bukannya menciptakan ruang public yang memungkinkan semua pihak bersuara. Konstruksi realitas Pilgub Sulsel 2018 untuk beberapa isu politik yang sensitif justru dikendalikan oleh kelompok yang berhasil menguasai ruang atau sarana penciptaan kesadaran publik. ${ }^{37}$ Kelompok dominan yang menguasai ruang, mengendalikan apa yang mesti dibaca atau dilihat oleh publik, sebab mengendalikan medium juga berarti memiliki kekuasaan untuk mengendalikan konten. Media karenanya menjadi sangat rentan memanipulasi informasi-atau meminjam istilah Boorstin-menciptakan peristiwa semu (pseudo event) di mana pengumpulan berita berubah menjadi "pembuatan" berita. ${ }^{38}$ Prinsip dasar media telah bergeser dari sebuah medium atau ranah publik yang memungkinkan keterlibatan kritis warga, menjadi sekedar instrumen kekuasaan untuk "merekayasa kesadaran". 39 
McChesney berpendapat bahwa jurnalisme politik yang pro kekuatan kapitalis merupakan anak kandung dari jurnalisme politik partisan di masa sebelumnya. Jika jurnalisme politik partisan secara terbuka mengungkapkan identitas keberpihakan politiknya kepada politisi atau partai politik tertentu, maka jurnalisme politik yang pro kapitalis lebih halus memainkan keberpihakannya kepada kekuatan politik yang menopang rutinitas media sebagai instituisi bisnis. ${ }^{40}$ Ketika jurnalisme telah diintervensi kepentingan komersil pemilik media, maka tidak akanditemukan suatu proses pemberitaan yang benar-benar bersifat netral. Idiologi di balik jurnalisme profesional tidak lain sebagai bentuk penghambaan terhadap pemilik modal dan pemasang iklan dalam suatu sistem media. Isi berita bukan ditujukan bagi kepentingan pembaca atau pemirsa, tetapi justru lebih diupayakan bagi kepuasan pemodal dan pemasang iklan yang notabene elit politik. Jurnalisme profesional telah menjadi suatu aktifitas kering yang kehilangan semangat independensi.

\section{KESIMPULAN}

Teks berita dan program siaran media lokal cenderung mengkonstruksi isu-isu populis mengenai realitas politik jelang Pilgub Sulsel 2018. Penonjolan kekuatan elit, parpol dan kelompok dominan serta pemarginalan posisi kontestan pilgub dikonstruksi dalam teks berita dengan penekanan pada elemen wacana; semantik, stilistik, skema relasi dan identitas aktor politik. Selain mendasarkan teksberita pada nilai magnitude peristiwa, rasionalitas survei, komentar pengamat politik, pernyataan opinion leader juga menjadi basis instrumental untuk melegitimasi gagasan redaktur/produser dalam pengkonstruksian realitas Pilgub Sulsel 2018. Konstruksi teks berita tentang realitas Pilgub Sulsel 2018 memberi kesan bahwa entitas media lokal berkarakter partisan, namun pemihakannya pada kepentingan kelompok dominan berlangsung secara samar dan dramatis dengan mengendalikan teks secara interdiskursif.

Praktik wacana di ruang redaksi menunjukkan peran sentral redaktur yang tidak hanya sebatas agen pendefinisi realitas (second definers), tetapi juga sebagai aktor politik dalam kontestasi wacana Pilgub Sulsel 2018. Redaktur memiliki kuasa atas teks yang mampu menciptakan isu politik dalam pemberitaan sekaligus berkuasa menentukan arah wacana yang dikonstruksinya. Namun kekuasaan redaktur atas konstruksi realitas di bawah tekanan kepentingan ekonomi politik media, sehingga mediasi pertarungan wacana dari berbagai kelompok sekedar diarahkan untuk pencapaian kepentingan politis dan ekonomis dari media itu sendiri. Praktik wacana dalam ruang redaksi karenanya tidak berlangsung netral atau steril dari pengaruh kepentingan ekonomi politik media di mana wartawan dan redaktur dituntut memainkan peran politik untuk berelasi dengan aktor politik pilgub dalam rangka memenuhi komoditas informasi dan kepentingan kapital pemilik media. 


\section{REFERENSI}

Barker, Chris. Cultural Studies: Teori dan Praktitk. Penerjemah, Cultural Studies Centre. Yogyakarta: PT. Bentang Pustaka, 2005.

Badara, Aris. Analisis Wacana: Teori, Metode, dan Penerapannya Pada Wacana Media. Jakarta: Kencana Prenada Group, 2012.

Eriyanto.Analisis Wacana; Pengantar Analisis Teks Media. Cet.VI; Yogyakarta; LKiS, 2008

Analisis Framing; Konstruksi, Ideologi dan Politik Media. Cet.I; Yogyakarta: LKiS, 2002

Fairclough, Norman. Critical Discourse Analysis: The Critical Study of Language. London: Longman, 1995

- Analysing Discourse: Textual Analysis for Social Research. London: Routledge, 2003

Halik, Abdul. Komunikasi Diskursus dan Demokrasi Deliberatif; Pendekatan Kritis Dalam Studi Komunikasi Politik. Cet, I; Makassar: Alauddin University Press, 2011

Hamad, Ibnu. Konstruksi Realitas Politik dalam Media Massa; Sebuah Studi Critical Discourse Analysis terhadap Berita-Berita Politik. Cet.I; Jakarta: Granit, 2004.

Ibrahim, Idi Subandy, Budaya Populer Sebagai Komunikasi; Dinamika Popscape dan Mediascape di Indonesia. Jogjakarta: Jalasutra , dan Yudi Latif. Bahasa dan Kekuasaan; Politik Wacana di Panggung Orde Baru. Cet.I; Bandung: Mizan 1996

, dan Bachruddin Ali Akhmad, Komunikasi dan Komodifikasi; Mengkaji Media dan Budaya dalam Dinamika Globalisasi. Cet.I; Jakarta: Yayasan Pustaka Obor Indonesia, 2014

McNair, Brian. AnIntroduction to Political Communication. terj, Imam Muttaqien. Pengantar Komunikasi Politik. Cet. I; Bandung: Nusa Media, 2016.

Putra, I Gusti Ngurah. Media, Komunikasi, dan Politik; Sebuah Kajian Kritis. Cet.I; Yogyakarta: Fisipol UGM, 2008

Sobur, Alex. Analisis Teks Media; Suatu Pengantar untuk Analisis Wacana, Analisis Semiotik, dan Analisis Framing.Cet.V; Bandung: Remaja Rosdakarya. 2006.

\section{Endnote}

${ }^{1}$ Ibnu Hamad, "Konstruksi Realitas Politik Dalam Media Massa; Studi Pesan Politik Dalam Media Cetak Pada Masa Pemilu 1999", Makara Sosial Humaniora, 8, No.1 (2004), h. 22. Lihat juga Brian McNair. An Introduction to Political Communication. terj, Imam Muttaqien. Pengantar Komunikasi Politik (Cet. I; Bandung: Nusa Media, 2016).

2 Idi Subandy Ibrahim, Budaya Populer Sebagai Komunikasi; Dinamika Popscape dan Mediascape di Indonesia (Jogjakarta: Jalasutra, 2011), h. 190.

3 Uraian lengkap mengenai tokoh-tokoh teori kritis lainnya dapat ditinjau dalam tulisan Abdul Halik, Komunikasi Diskursus dan Demokrasi Deliberatif, h. 13. Lihat juga Novri Susan, Pengantar Sosiologi Konflik dan Isu-Isu Konflik Kontemporer (Jakarta: Kencana Prenada Media Group, 2010) h. $20-21$ 
${ }^{4}$ Eriyanto, Analisis Wacana, h. 32-46

${ }^{5}$ Eriyanto, Analisis Wacana, h. 14-15

6 Yoce Aliah, Analisis Wacana Kritis Dalam Multiperspektif (Bandung: PT Refika Aditama, 2014), h. 1

${ }^{7}$ Eriyanto, Analisis Wacana, h. 4-6

${ }^{8}$ Eriyanto, Analisis Wacana, h. 7

9 Eriyanto, Analisis Wacana, h. 8-14, dan Yoce Aliah, Analisis Wacana Kritis Dalam Multiperspektif, h. $135-144$

${ }^{10}$ Eriyanto, Analisis Wacana, h. 305

${ }^{11}$ Eriyanto, Analisis Wacana, h. 285-286.

${ }^{12}$ Ramlan Surbakti, Memahami Ilmu Politik (Cet.VII; Jakarta: PT.Grasindo, 2010), 152

${ }^{13}$ Abdul Halik, Komunikasi Diskursus dan Demokrasi Deliberatif, h. iii.

${ }^{14}$ Michael Rush dan Philip Althoff, Pegantar Sosiologi Politik (Jakarta: RajaGrafindo Persada, 2003), h. 24

${ }^{15}$ Robert G. Meadow, Politics as Communication (New Jersey: Alex Publishing Co, 1980) dalam Anwar Arifin, Perspektif Ilmu Politik, h. 67. Lihat juga uraian AA.Said Gatara dan Moh.Dzulkiah Said, Sosiologi Politik; Konsep dan Dinamika Perkembangan Kajian, h. 141

${ }^{16}$ Michael Rush dan Philip Althoff, Pegantar Sosiologi Politik, h. 24 dan 253

${ }^{17}$ Brian McNair, An Introduction to Political Communication, h. 5

${ }^{18}$ Brian McNair, An Introduction to Political Communication, h. 13-14

${ }^{19}$ I Gusti Ngurah Putra. Media, Komunikasi, dan Politik; Sebuah Kajian Kritis, h. 85-86

${ }^{20}$ Brian McNair, An Introduction to Political Communication, h. 65

${ }^{21}$ Lihat lebih mendalam uraian I Gusti Ngurah Putra. Media, Komunikasi, dan Politik; Sebuah Kajian Kritis, h. 89

${ }^{22}$ I Gusti Ngurah Putra. Media, Komunikasi, dan Politik; Sebuah Kajian Kritis, h. 91

${ }^{23}$ I Gusti Ngurah Putra. Media, Komunikasi, dan Politik; Sebuah Kajian Kritis, h. 90-93

${ }^{24}$ Idi Subandy Ibrahim dan Bachruddin Ali Akhmad, Komunikasi dan Komodifikasi, h. 15

${ }^{25}$ Abdul Halik, Komunikasi Diskursus dan Demokrasi Deliberatif, h. 110-112

${ }^{26}$ Idi Subandy Ibrahim dan Bachruddin Ali Akhmad, Komunikasi dan Komodifikasi, h. 17-21

${ }^{27}$ I Gusti Ngurah Putra. Media, Komunikasi, dan Politik; Sebuah Kajian Kritis, h. 69 dan 95-97

28 Jika dicermati antara satu berita dengan berita lainnya (contoh berita "Ketat, Saling Kejar Elektabilitas-14/06/2017 dan "Persaingan Ketat di Tiga Besar-23/06/17)" ditemukan kecenderungan perbedaan hasil survei dari satu lembaga survei dengan lembaga survei lainnya. Di satu pihak, ada lembaga survei yang lebih dominan memaparkan data keunggulan pasangan cagub, sedangkan posisi pasangan cagub lainnya cenderung terpinggirkan. Sementara itu data hasil survei dari lembaga survei yang lainnya justru menggambarkan kondisi yang berbeda tentang derajat popularitas dan elektabilitas masing-masing kandidat

${ }^{29}$ Pada teks berita "Ketat, Saling Kejar Elektabilitas (14/06/2017)" tidak ditemukan paparan data yang detil mengenai elektabilitas cagub Sulsel 2018 sehingga tampak kecenderungan nominalisasi dengan menyamarkan fakta bahwa elektabilitas masing-masing cagub Sulsel 2018 "berfluktuatif". Nuansa nominalisasi juga ditemukan pada paragraf yang membahas segi popularitas cagub Sulsel 2018, wacana popularitas IYL cenderung diperbesar atau dikedepankan sedangkan wacana popularitas kandidat lain terutama $\mathrm{NH}$ dinominalisasi dalam teks.

${ }^{30} \mathrm{Hal}$ ini misalnya diungkapkan oleh redaktur politik Harian Fajar, Dalam konteks penulisan berita, nilai berita menjadi pertimbangan dalam pemberitaan calon gubernur. Misalnya perseteruan mengunci rekomendasi, saling kritik antarcalon, dan gagasan baru yang mereka usung. Gagasan 
paling baru atau aktivitas paling menarik, akan mendapatkan ruang publikasi. Prioritas pemberitaan adalah yang paling memiliki magnitude (daya dentum). Ridwan Marzuki, Redaktur Politik Harian Fajar. Wawancara, Kantor Redaksi Harian Fajar, 1 November 2017.

${ }^{31}$ Lihat uraian I Gusti Ngurah Putra. Media, Komunikasi, dan Politik; Sebuah Kajian Kritis, h. 142. Lihat juga Lihat uraian Nugroho, Putri, dan Laksmi. Memetakan Lanskap Industri Media Kontemporer di Indonesia (Jakarta: CPIG dan Hivos, 2012), h. 19

32 Jawa Pos Group telah mengembangkan bisnisnya dengan mengakuisisi beberapa surat kabar lokal dan menggabungkannya di bawah nama Radar Group. Saat ini, Jawa Pos Group memiliki 171 perusahaan media cetak yang tersebar di seluruh Indonesia, ditambah sejumlah jaringan televisi lokal (120 stasiun) di seluruh Indonesia

${ }^{33}$ Harian Fajar juga mengembangkan sayap ke bisnis nonmedia, antara lain universitas, agrobisnis, transportasi, dan lainnya. Kantor di Jalan Racing Centre menjadi saksi bagaimana Fajar selama kurun waktu 16 tahun (1991-2007) merangkak naik menjadi yang terbesar di luar pulau Jawa dan pemimpin pasar di Timur Indonesia, posisi tertinggi dalam level bisnis surat kabar.

${ }^{34}$ Bosowa Corp adalah perusahaan induk (holding company) yang memiliki berbagai bidang bisnis (10 unit bisnis), antara lain semen, energi, pertambangan, infrstruktur, pendidikan, yayasan, sumber daya alam, media, otomotif, keuangan, properti, transportasi, logistik, dan lainnya.

${ }^{35}$ Pada Harian Fajar misalnya, antara iklan politik dan berita politik hampir tidak dapat dibedakan lagi. Halaman surat kabar dijual sebagai iklan politik, akan tetapi bentuk, tata letak dan teksnya sama dengan berita. Implikasinya kemudian adalah praktik politik ruang, di mana pembelian iklan yang sebenarnya sama saja dengan memuat berita dengan membayar. Iklan politik tersebut isnya adalah berita-berita yang menggambarkan event politik para kandidat Pilgub Sulsel 2018, yang diurai secara panjang lebar dengan teks dan gambar, misalnya kunjungan di beberapa daerah dalam rangka sosialisasi politik atau dibahasakan secara politis sebagai silaturrahmi kepada warga setempat.

${ }^{36}$ Lihat misalnya berita"Pilkada Serentak Ujian Berat Golkar (18/07/2017)" yang memaparkan dugaan (hipotesis dan praanggapan) bahwa Golkar akan menghadapi masalah pada pilkada serentak 2018 karena kasus yang menimpa elit Golkar, Setya Novanto sebagai tersangka kasus korupsi KTPelektronik. Wartawan Harian Fajar memaparkan fakta-fakta yang mampu membuktikan bahwa Golkar memang menghadapi ujian berat, terutama jika dikaitkan dengan latar pemberitaan yang menyoroti kasus Setya Novanto dan implikasinya terhadap pertarungan Golkar di Pilgub Sulsel 2018.

${ }^{37}$ Herman dan Chomsky dalam bukunya "Manufacturing Consent" mengemukakan bahwa cara di mana kesadaran warga 'direkayasa' melalui konten media adalah sama dengan propaganda. Perspektif yang ditawarkan oleh Herman dan Chomsky juga dapat digunakan untuk menjelaskan cara media bekerja di Indonesia. Lihat uraian Nugroho, Putri, dan Laksmi. Memetakan Lanskap Industri Media Kontemporer di Indonesia, h. 18

${ }^{38}$ Boorstin lebih lanjut mengatakan bahwa dalam masyarakat demokrasi, kebebasan berbicara, kebebasan pers dan penyiaran, mencakup juga kebebasan untuk "menciptakan persitiwa semu". Para aktor politik, wartawan dan media berlomba-lomba menciptakan peristiwa semu, menawarkan laporan dan gambaran keadaan menarik dan informatif. Mereka bebas berspekulasi mengenai fakta, memunculkan fakta-faka baru, dan menuntut jawaban atas pertanyaan-pertanyaan yang mereka buat sendiri. Pasar bebas gagasan merupakan tempat di mana orang dihadapkan pada berbagai peristiwa semu dan dipersilangkan untuk menilainya. Lihat uraian Brian McNair, An Introduction to Political Communication, h. 31-32

${ }^{39}$ Nugroho, Putri, dan Laksmi. Memetakan Lanskap Industri Media Kontemporer di Indonesia, h. 13

${ }^{40}$ I Gusti Ngurah Putra. Media, Komunikasi, dan Politik; Sebuah Kajian Kritis, h. 90 